\title{
Work stressors, job insecurity, union support, job satisfaction and safety outcomes within the iron ore mining environment
}

\begin{tabular}{|c|c|}
\hline \multicolumn{2}{|c|}{$\begin{array}{l}\text { Authors: } \\
\text { Nicolaas W.H. Smit }{ }^{1} \\
\text { Leon T. de Beer } \\
\text { Jaco Pienaar }\end{array}$} \\
\hline \multicolumn{2}{|c|}{$\begin{array}{l}\text { Affiliations: } \\
{ }^{1} \text { WorkWell Research Unit, } \\
\text { North-West University, } \\
\text { Potchefstroom Campus, } \\
\text { South Africa }\end{array}$} \\
\hline \multicolumn{2}{|c|}{$\begin{array}{l}\text { Corresponding author: } \\
\text { Leon de Beer, } \\
\text { debeer.leon@nwu.ac.za }\end{array}$} \\
\hline \multicolumn{2}{|c|}{$\begin{array}{l}\text { Dates: } \\
\text { Received: } 28 \text { May } 2015 \\
\text { Accepted: } 01 \text { June } 2016 \\
\text { Published: } 19 \text { Aug. } 2016\end{array}$} \\
\hline \multicolumn{2}{|c|}{$\begin{array}{l}\text { How to cite this article: } \\
\text { Smit, N.W.H., De Beer, L.T., \& } \\
\text { Pienaar, J. (2016). Work } \\
\text { stressors, job insecurity, } \\
\text { union support, job } \\
\text { satisfaction and safety } \\
\text { outcomes within the iron ore } \\
\text { mining environment. SA } \\
\text { Journal of Human Resource } \\
\text { Management/SA Tydskrif vir } \\
\text { Menslikehulpbronbestuur, } \\
\text { 14(1), a719. http://dx.doi. } \\
\text { org/10.4102/sajhrm. } \\
\text { v14i1.719 }\end{array}$} \\
\hline \multicolumn{2}{|c|}{$\begin{array}{l}\text { Copyright: } \\
\text { (C) 2016. The Authors. } \\
\text { Licensee: AOSIS. This w } \\
\text { is licensed under the } \\
\text { Creative Commons } \\
\text { Attribution License. }\end{array}$} \\
\hline \multicolumn{2}{|l|}{ Read online: } \\
\hline 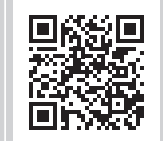 & $\begin{array}{l}\text { Scan this QR } \\
\text { code with your } \\
\text { smart phone or } \\
\text { mobile device } \\
\text { to read online. }\end{array}$ \\
\hline
\end{tabular}

Orientation: The study of work stressors, job insecurity and union support creates opportunity for iron ore mining organisations to manage job satisfaction and safety motivation and behaviour more effectively.

Research purpose: The objective of this study was to investigate the relationship between work stressors, job insecurity, union support, job satisfaction and safety motivation and behaviour of a sample of iron ore mine workers in South Africa.

Motivation for the study: The mining industry in general is often faced with hazardous and physically demanding working environments, where employees work under constant pressure. Work stressors, job insecurity, union support and job satisfaction are considered key variables when investigating effective means of managing safety.

Research design, approach and method: A cross-sectional survey design was utilised to collect the data. A convenience sample of employees in the iron ore mining industry of South Africa $(N=260)$ were included. Structural equation modelling and bootstrapping resampling analysis were used to analyse the data.

Main findings: Work stressors and job insecurity were found to be negatively associated with job satisfaction. Conversely, perceived union support was positively associated with job satisfaction and safety motivation and behaviour. Furthermore, job satisfaction mediated the relationship between union support and safety motivation and behaviour.

Practical/managerial implications: Mining organisations can, by placing the focus on reducing work stressors, and promoting job security and union support, achieve higher levels of safety motivation and behaviour through job satisfaction.

Contribution/value-add: A great deal of independent research on work stressors, job insecurity, union support, job satisfaction as well as safety motivation and behaviour has already been done. To date, very little empirical research exists that simultaneously considers all these constructs. This study brought together these lines of research.

\section{Introduction}

South Africa is one of the world's leaders in the mining industry, known for its rich mineral resources, and contributing significantly to both world production and reserves. The mining industry of South Africa is a dominant force globally and locally a large contributor to GDP. According to the Chamber of Mines, the mining industry provides approximately one million jobs - spending R 78 billion in wages and salaries (Smit, 2013) and accounting for about $18 \%$ of GDP. In 2012, the mining industry contributed R 468 billion to South Africa's economy, accounting for over $16 \%$ of the formal sector employment (Kumo, Rielander \& Omilola, 2014). Therefore, it is evident that mining plays a pivotal role in the South African economy.

However, of concern is the poor safety record and number of fatalities within the South African mining industry. Total fatalities were 221 in 2007, 168 in 2008, 169 in 2009, 128 in 2010, 123 in 2011 and 112 in 2012, the lowest ever recorded (Department of Mineral Resources, 2013). Even though an improvement in the fatality rate has been evident over the last couple of years, mining is still regarded as one of the most dangerous and hazardous occupations in South Africa (Le Roux, 2005; Paul \& Maiti, 2005).

Note: This article is based on the author's mini-dissertation of the degree of Magister Commercii in Industrial Psychology at the Potchefstroom Campus, North-West University, South Africa, with supervisor Prof. J. Pienaar and co-supervisor Dr L.T. de Beer, received November2014,availablehere:http://dspace.nwu.ac.za/bitstream/handle/10394/15554/Smit_NWH_2014.pdf?isAllowed=y\&sequence=1 
Employees are exposed to several job demands every day. These workplace demands entail continuous physical and psychological effort, which in turn may have important physiological and psychological implications (Bakker, Demerouti \& Schaufeli, 2003; Demerouti, Bakker, Nachreiner \& Schaufeli, 2001). The manifestation of job demands has been associated with increased levels of burnout and decreased job performance (e.g. Bakker et al., 2003). In high-risk work environments, such as the mining environment, challenging physical and cognitive job demands as well as exposure to hazardous materials are present. These job demands have the potential to cause very negative consequences, such as workplace accidents, injuries and fatalities.

Fortunately, the workplace also provides employees with job resources, to enable them to cope with the demands they face (Crawford, Lepine \& Rich, 2010). According to Demerouti et al. (2001), job resources diminish job demands and their associated physiological cost. Resources have also been shown to increase employee engagement, performance and job satisfaction (Bakker \& Demerouti, 2007; Rich, LePine \& Crawford, 2010). Therefore, if employees are faced with insufficient job resources, they may not be able to efficiently deal with challenging demands which may have undesired consequences, such as not adhering to safety rules and regulations (Probst \& Brubaker, 2001).

In research conducted on workplace safety, emphasis has been placed on the role of the work environment when considering safety in the workplace (Ghosh, Bhattacherjee \& Chau, 2004). Literature consistently shows a negative relationship between work stressors and various outcomes, such as a lack of job satisfaction, lower organisational commitment, decreased job performance and increased turnover (Gilboa, Shirom, Fried \& Cooper, 2008; Karsh, Booske \& Sainfort, 2005; Podsakoff, LePine \& LePine, 2007; Yousef, 2002). Work stressors, such as performance pressure, time constraints and targets that have to be reached within strict deadlines, may encourage employees to take shortcuts, thereby putting themselves at risk by jeopardising safety rules and regulations. The alleviation of excessive work stressors is a great challenge for employees, considering the deleterious effect work stressors can have on their health and organisational outcomes such as organisational commitment, job satisfaction and the occurrence of workplace fatalities and accidents (Gyekye, 2005). These findings generally demonstrate that increased work stressor levels have a negative effect on the safety compliance of employees.

Likewise, job insecurity is regarded as a major concern in the mining industry and a demanding aspect of work. Restructuring and organisational downsizing are realities feared by many employees. Studies have shown that employees who reported experiencing job insecurity were less likely to experience job satisfaction (Blanchflower \& Oswald, 1999; Chirumbolo \& Areni, 2005). Additionally, they suffered negative physical health consequences (Richter,
2011) and showed a lack of compliance with safety regulations (Probst \& Brubaker, 2001).

In the South African mining industry, strikes and industrial actions (both legal and illegal) are some of the major threats. This has been particularly problematic because of the increase in radicalism of trade unions (and militant workers) as well as the influence of political factions (Seseane, 2014). For example, the 5-month-long strike in the platinum sector resulted in a catastrophic loss for both mine investors and mining workers, with an estimated total loss of R24 bn. Now the platinum sector is considering retrenchments to try and recover some of the losses (Marrian, 2015; Steyn, 2014). Furthermore, the double-edged sword of technology (automation) in the industry could have an additional impact on future employment numbers (Begley, 2013) - indicating the potential for further job losses. Although the impact of job insecurity on employee attitude and behaviours as well as important organisational outcomes has been well explored, research regarding the implications of job insecurity on employee safety is still relatively unexplored within the mining environment of South Africa (Masia \& Pienaar, 2011).

As mentioned earlier, the workplace ought to provide employees with resources to cope with the ever increasing demands they are faced with. Union support may be regarded as such a job resource, insofar as unions protect their workers from potential unethical treatment and ensure they are treated in a fair and humanistic way (Goslinga \& Sverke, 2003; Hellgren \& Chirumbolo, 2003). Unions may play a critical role in the enforcement and updating of safety policies, occurring through formal training and monitoring labour sites (i.e. the employees' working environments). A tendency exists for union representatives to exercise their right by inspecting these policies and procedures more often than non-union members (Weil, 1999). This happens in conjunction with the health and safety representatives of different sections where there are more than 20 employees per section. Managers at union sites are thereby encouraged to comply with occupational health and safety regulations and other additional safety practices (Masia \& Pienaar, 2011; Ringen, Englund, Welch, Weeks \& Seegal, 1995).

In a South African study conducted by Masia and Pienaar (2011) in the gold mining environment, job satisfaction was found to be a predictor of safety compliance. Job satisfaction is known to be an accurate indicator of workers' feelings towards their job, duties and work environment (Sverke et al., 2004). According to Dunbar (1993), job dissatisfaction has a negative impact on employees' use of protective equipment. Another study found that one of the consequences of job dissatisfaction among employees may lead to decreased effort, thereby increasing error rate culminating in higher incident and fatality rates (Probst, 2002; Salminen, 1995). Job dissatisfaction may have several undesirable outcomes, including a lack of compliance with safety rules and regulations, consequently contributing to the number of accidents and incidents in the workplace. 
The objective of this study was to assess the relationship between work stressors, job insecurity, union support and outcomes, such as job satisfaction, safety motivation and behaviour. The results are important in aiding organisations towards identifying factors that can increase job satisfaction and safety motivation and behaviour, as well as factors that may impede these desired outcomes.

\section{Literature review}

\section{Work stressors}

The term work stressor is used to describe the pressure employees experience as a result of organisational and jobspecific factors in the form of demands and constraints that are placed on them at work (Kahn, Wolfe, Quinn, Snoek \& Rosenthal, 1964). Three of the most examined types of work stressors are role conflict, role clarity (ambiguity) and role overload (Balducci, Cecchin \& Fraccaroli, 2012; Rizzo, House \& Lirtzman, 1970), indicating the use of these constructs for more than four decades.

Role conflict can be described as the inconsistent and conflicting expectations between colleagues where interferences within one another's work areas complicate work completion (Katz \& Kahn, 1978). Rizzo et al. (1970) are of the opinion that role conflict is demonstrated in numerous ways: (1) through workers' internal values and expected job behaviours; (2) through time, resources or skills and abilities of workers; (3) through workers fulfilling numerous roles which may lead to incompatible behaviour; and finally (4) through inconsistent expectations and organisational demands.

Role clarity can also be, conversely, referred to as role ambiguity, indicating that the individual has ambiguous or indefinite expectations regarding his or her roles and responsibilities (Kahn et al., 1964; Katz \& Kahn, 1978). Plenty of research has shown that role stressors may contribute largely to work attitudes and strain (Balducci et al., 2012; O'Driscoll \& Beehr, 1994; Stordeur, D'hoore \& Vandenberghe, 2001). Various studies of role stressors have established that role conflict and role clarity have a significant influence on employees' level of job satisfaction, anxiety, emotional exhaustion and organisational commitment (Fried, Shirom, Gilboa \& Cooper, 2008; Jackson \& Schuler, 1985; Örtqvist \& Wincent, 2006).

Role overload can be described as the amount of work an employee is required to do within an expected time frame (Cooper, Dewe \& O'Driscoll, 2001). Role overload occurs when employees' work tasks entail more time and effort than they have available to adequately perform their expected roles. Results from literature yielded that role overload is associated with increased levels of strain, in addition to poor job performance, increased turnover and decreased levels of job satisfaction (Cooper et al., 2001; Griffeth, Hom \& Gaertner, 2000; Judge, Thoresen, Bono \& Patton, 2001; Mathieu \& Zajac, 1990). Role overload is a crucial factor in the mining industry because workers are expected to be productive, work overtime and to maintain high levels of work engagement (Pienaar, Sieberhagen \& Mostert, 2007).

\section{Job insecurity}

The subcontracting of labour and the significant impact thereof on job security have received growing recognition in the mining industry over the last few decades (Kenny \& Bezuidenhoud, 1999). Job insecurity is defined by Greenhalgh and Rosenblatt (1984) as a 'sense of powerlessness to maintain desired continuity in a threatened job situation' (p. 438) and was consequently measured as a unidimensional phenomenon; however, Hellgren, Sverke and Isaksson (1999) distinguished between quantitative and qualitative job insecurity. Quantitative job insecurity refers to employees' concerns regarding the prospects of the present job, whereas qualitative job insecurity refers to employees' fear of reduced quality in the work relationship (concerning aspects such as features of the job, career progression and salary increases). According to Hellgren et al. (1999), job insecurity is subjective, and therefore, although employees are exposed to similar situations, they may react in different ways when uncertainty about the future occurs. Research revealed that the anticipation of potential job loss can be regarded as a work stressor, which can have short-term negative effects on employees' work attitudes, that is, job satisfaction and turnover intention, while in the long term it may affect employees' overall well-being and health (Cheng \& Chan, 2008; De Witte, Pienaar \& De Cuyper, 2016; Sverke, Hellgren \& Näswall, 2002).

\section{Union support}

Traditionally, the role of a union is to establish a workplace where members' rights for fair treatment and a safe work environment are protected (Cregan, 2005; Kochan, Katz \& McKersie, 1986). Employees often join unions in the belief that the presence of a union will improve their working conditions (Hartley, Jacobson, Klandermans \& Van Vuuren, 1991). In a study conducted by Greenhalgh and Rosenblatt (1984), they found that the role of the union is to minimise the feeling of helplessness when it comes to job insecurity; employees feel more secure because of the power and negotiating position in aiding them to retain their jobs. Furthermore, Sverke et al. (2004) found that union members have different experiences in terms of job insecurity, job satisfaction and organisational commitment as compared to non-members. Another example of these differences includes Borjas' study (Borjas, 1979) in which it was found that union support has a positive relationship with job satisfaction. In the light of the roles unions occupy, Shore, Tetrick, Sinclair and Newton (1994) describe perceived union support as 'members' global beliefs concerning the extent to which the union values their contributions and cares about their wellbeing' (p. 971). The effect of union support can be explained on the basis of the social exchange theory, suggesting that when members feel they receive support from their unions, they may in turn feel an obligation to be devoted and dedicated towards their union (Goslinga et al. 2005). 


\section{Job satisfaction}

Job satisfaction is defined as 'a pleasurable emotional state that results from the appraisal of one's job as achieving or facilitating one's job values' (Locke, 1969, p. 317); whereas job dissatisfaction is defined as 'the unpleasable emotional state resulting from the appraisal of one's job as frustrating or blocking the attainment of one's values' (Locke, 1969, p. 317).

Researchers such as Weiss, Nicholas and Daus (1999) distinguished between job satisfaction as being either an emotional reaction or an attitude employees hold about their job. Job satisfaction, according to Spector (1997), simply refers to the degree to which employees like or dislike their jobs. Therefore, it is clearly evident that job satisfaction is a strong indicator of employees' feelings regarding their job. Job satisfaction is often a direct reaction towards immediate working conditions. In a study done by Vandenberghe, Panaccio, Bentein, Mignonac and Roussel (2011), for example, they found that employees who experienced high levels of role conflict and role overload tend to experience low levels of job satisfaction. It is evident that role conflict and role overload limit employees from being effective in their work tasks, consequently decreasing satisfaction derived from their job. Thus, empirical literature confirms that job satisfaction is directly associated with employees' working conditions and that increased work stressors are related to decreased levels of job satisfaction (Acker, 2004; OrgambídezRamos, Borrego-Alés \& Mendoza-Sierra, 2014).

\section{Safety motivation and -behaviour}

In the mining industry, productivity, pressure and strict deadlines are emphasised creating a tendency among many workers to engage in unsafe behaviours (Janssens, Brett \& Smith, 1995). Neal and Griffin (2006) describe safety motivation as an employee's preparedness to exert effort to enact safety behaviours as well as the eagerness linked to those behaviours (Neal \& Griffin, 2006). Employees who perceive their work environment to be safety conscious have the tendency to be more motivated to partake in safety activities and are more likely to comply with safety rules and regulations - thus exhibiting safety behaviour (Griffin \& Neal, 2000). Evidence to support this statement is provided in a longitudinal study conducted by Probst and Brubaker (2001), in which the effect of safety motivation has a prolonged impact on safety compliance up to 6 months later. Furthermore, it has been argued that theories of work performance offer a valuable foundation for conceptualising the relationship between safety climate and safety behaviour (Griffin \& Neal, 2000).

Borman and Motowidlo (1993) distinguish between two types of safety behaviour, namely: compliance and participation. Neal and Griffin (2006) describe safety compliance as the essential behaviours employees need to adhere to in order to maintain safe working conditions. These crucial behaviours include following standard work policies and procedures, as well as wearing protective gear. Safety participation, on the other hand, describes behaviours that are not directly linked to individuals' personal safety, but rather to develop safe working conditions (Griffin \& Neal, 2000). These behaviours comprise taking part in voluntary safety activities, assisting fellow workers with safety-related matters and attending safety meetings. South African research has found that management commitment plays a vital role in safety contexts, especially where there is tension regarding production deadlines and safety procedures (Bosak, Coetsee \& Cullinane, 2013).

\section{The relationship between work stressors and job satisfaction}

Work stressors have been identified as a concern that manifests itself in employee absenteeism, turnover and reduced productivity (Karasek \& Theorell, 1990). Similarly, a variable closely associated with work stressors is job satisfaction. Numerous researchers have shown that job satisfaction plays a vital role in an organisation, because of its significant relationships with important organisational outcomes such as job insecurity, intention to leave and safety behaviour (Paul \& Maiti, 2005; Probst \& Brubaker, 2001; Saks, 2006). Work stressors, in particular role conflict, role clarity and role overload, have previously been classified as organisational factors associated with burnout and lower levels of job satisfaction (Acker, 2004, Carlson, Kacmar \& Williams, 2000). The multiple stressors employees experience in the workplace can lead to risky decisions in completing their work tasks because of limited time. Stress in the workplace is known to be caused by role conflict, role clarity and role overload that negatively influence job satisfaction suggesting that the less work stressors employees perceive, the more job satisfaction they should report (Kahn et al., 1964; Rizzo et al., 1970):

- Hypothesis 1a: Work stressors will be negatively related to job satisfaction.

\section{The relationship between work stressors and safety motivation and behaviour}

Organisations are constantly striving to increase production, without taking into account that employees may often neglect safety procedures in an attempt to reach their performance targets (Probst \& Brubaker, 2001). These findings seem to be consistent with other research which has found that work stressors have a negative impact on employee safety motivation and behaviour (Hofmann \& Stetzer, 1998). A possible explanation for these results may be found in a study where the researchers emphasise that an overload of employee tasks and responsibilities, impracticality of their job demands and a lack of awareness may have a significant impact on employees' safety motivation and behaviour and should be considered during accident investigation (Ashworth \& Peake, 1994):

- Hypothesis 1b: Work stressors will be negatively related to safety motivation and behaviour.

\section{The relationship between job insecurity and job satisfaction}

One of the most consistent findings in literature is that job insecurity is closely associated with job satisfaction 
(Delp, Wallace, Geiger-Brown \& Muntaner, 2010; De Witte, 1999; Näswall \& De Witte, 2003; Ouyang, Sang, Li \& Peng, 2015; Sverke \& Hellgren, 2002). Kaiser (2002) investigated the job satisfaction of employees with several types of contracts, such as full-time permanent, full-time fixed-term, part-time permanent, part-time fixed-term, and self-employment. It was found that permanently employed and part-time workers expressed less job insecurity and more job satisfaction than those employees who were either employed fixed-term or self-employed. It is therefore evident that workers' job insecurity influences their level of job satisfaction:

- Hypothesis 2a: Job insecurity will be negatively related to job satisfaction.

\section{The relationship between job insecurity and safety motivation and behaviour}

Research has indicated that job insecurity is negatively correlated to the utilisation of protective equipment (Dunbar, 1993). Therefore, job insecurity negatively impacts compliance with safety policies, rules and regulation and consequently gives rise to potential accidents and safetyrelated incidents in the workplace (Ashford, Lee \& Bobko, 1989; Probst \& Brubaker, 2001).

These findings can be explained in the light of the social exchange theory, which states that employees have beliefs regarding the degree to which they are valued, treated fairly and cared about by their organisation (Eisenberger, Huntington, Hutchinson \& Sowa, 1986). In turn, employees may demonstrate positive attitudes towards the organisation, exhibiting more satisfaction and more commitment (Rhoades \& Eisenberger, 2002). Therefore, employees who experience less job insecurity may perceive more organisational concern and support, consequently generating more secure, motivated and committed employees:

- Hypothesis 2b: Job insecurity will be negatively related to safety motivation and behaviour.

\section{The relationship between union support and job satisfaction}

Unions also have an impact on management practices focused on examining a range of workplace policies, such as work hours, wages, subcontracting (cf. Bolton et al., 2007). Among the positive effects of unions, Slichter, Healy and Livernash (1960) emphasise improved communication and a better balance between management and workers' interests. Unions aim to improve members' working life by improving workplace conditions through negotiation, collective bargaining and the successful handling of grievances. Thus, it is expected that a positive relationship exists between union support and job satisfaction (Lillydahl \& Singell, 1993):

- Hypothesis 3a: Union support will be positively related to job satisfaction.

\section{The relationship between union support and safety motivation and behaviour}

Differences have been found between union members' and non-union members' responses to the topic of safety in the workplace, that is, union members have been found to perceive their supervisors as being more concerned with their safety than non-union members (Gillen, Baltz, Gassel, Kirsch \& Vaccaro, 2002). Furthermore, it has been found that union workers are more aware of dangerous work practices and participate more frequently in regular job safety meetings; unionised workplaces also seem to have the tendency to offer additional training and other formal systems, such as safety policies (Verma, 2005). Because unions play a vital role in establishing safety standards and enforcing better reporting systems, they are expected to have a positive association with workplace safety (Spigener \& Hodson, 1997). Finally, Verma (2005) pointed out that workplaces represented by a union are more likely to have labour inspections than non-unionised workplaces, even when the health and safety legislation is applied to both union and non-unionised workplaces (Weil, 1992):

- Hypothesis 3b: Union support will be positively related to safety motivation and behaviour.

\section{The relationship between job satisfaction and safety motivation and -behaviour}

Probst and Brubaker (2001) found noteworthy evidence that job satisfaction is an important predictor of safety motivation and knowledge. This finding suggests that labourers who are satisfied with their work are more likely to comply with safety rules and regulations, thus exhibiting safety behaviour. Therefore, it is possible that higher levels of job satisfaction may bring about higher overall safety motivation and compliance. These findings are confirmed in previous studies (Ashworth \& Peake, 1994; Hayes, Perander, Smecko \& Trask, 1998; Probst \& Brubaker, 2001). Other researchers have also indicated that job satisfaction is important in relation to the perceptions of the safety climate (Barling, Kelloway \& Iverson, 2003; Gillen et al., 2002; Paul \& Maiti, 2005). Once again, the social exchange theory can be used to explain this relationship. According to this theory, when employees feel valued by their organisations, they feel an obligation to respond positively in return. Therefore, when employees experience satisfaction at work, they often also feel satisfied with workplace conditions and may in turn feel a need to react in a way that will be beneficial for the organisation (Blair, 1999). Likewise, when employees are dissatisfied at work, they may allow conditions to deteriorate. This may include reduced effort as well as an increased error rate, which may lead to higher safety incident rates (Probst \& Brubaker, 2001):

- Hypothesis 4: Job satisfaction will be positively related to safety motivation and behaviour.

\section{Potential indirect effect(s) and mediation}

Job satisfaction plays a vital role in workplace attitudes and behaviours (Orgambídez-Ramos et al., 2014). Considering the negative impact of low levels of job satisfaction, it is crucial to investigate factors that may influence job satisfaction, as well as programmes that address job satisfaction, and, in turn, reduce negative work behaviours. Previous research identified job satisfaction as a mediator between the external 
job demands (stressors such as role conflict, ambiguity and overload in the climate) and work-related outcomes (such us safety behaviour) (Ashworth \& Peake, 1994; Paul \& Maiti, 2005; Probst \& Brubaker, 2001):

- Hypothesis 5: Job satisfaction mediates the relationship between work stressors, job insecurity, union support and safety motivation and behaviour.

\section{Research method \\ Research approach}

For this study, a quantitative approach was followed. According to Struwig and Stead (2001), quantitative research is based on larger samples of participants and structured, to a certain extent, by measuring the constructs of the study utilising a questionnaire. An electronic questionnaire was used, as well as pen-and-paper surveys. The questionnaire consisted of items measuring the constructs that were introduced in the literature study. The different constructs were measured simultaneously and at one specific time, which makes the broader approach cross-sectional in nature (Salkind, 2009).

\section{Participants}

For the purpose of this study, 320 employees were approached in a mining environment, such as shift bosses and supervisors who deal hands-on with unions and safety behaviour of their employees on a daily basis. The participation rate was $81.25 \%$ $(N=260)$ Furthermore, the sample included a combination of two mines from the same organisation, one in the Gauteng province and the other in Limpopo province. The sample group represented the iron ore open cast mining industry of South Africa. The characteristics of the participants are displayed in Table 1.

\section{Measuring instruments}

\section{Biographical questionnaire}

The biographical questionnaire consisted of questions relating to age (year of birth), gender, education, employment status and union membership.

\section{Work stressors}

It was scored as a composite variable measured by items from role conflict, role overload (quantitative), role overload (qualitative) and role (goal) clarity scales. Other researchers have also applied this strategy as an indication of work stress (e.g. Masia \& Pienaar, 2011). The Role conflict scale contained items based on how the employee thinks he should do the work compared to how his supervisor and superiors tell him the work should be done. This scale was originally invented by Rizzo et al. (1970). An example item of this construct was 'I receive incompatible requests from two or more people'; measured on a 5-point scale ranging from 1 (strongly disagree) to 5 (strongly agree). The Role overload scale comprised seven items (three qualitative and four quantitative), measured on a 5-point scale ranging from 1
TABLE 1: Characteristics of the participants.

\begin{tabular}{|c|c|c|c|}
\hline Item & Category & Frequency & Percentage (\%) \\
\hline \multirow[t]{2}{*}{ Gender } & Male & 228 & 87.70 \\
\hline & Female & 32 & 12.30 \\
\hline \multirow[t]{6}{*}{ Age in years } & $70-79$ & 1 & 0.40 \\
\hline & $60-69$ & 2 & 0.80 \\
\hline & $50-59$ & 32 & 12.30 \\
\hline & $40-49$ & 62 & 23.80 \\
\hline & $30-39$ & 118 & 45.30 \\
\hline & $20-29$ & 40 & 15.40 \\
\hline \multirow[t]{6}{*}{ Education } & Grade 10 & 38 & 14.60 \\
\hline & Grade 11 & 41 & 15.80 \\
\hline & Grade 12 & 104 & 40.00 \\
\hline & Diploma & 35 & 13.50 \\
\hline & Technikon Diploma & 10 & 3.80 \\
\hline & Postgraduate degree & 16 & 6.20 \\
\hline \multirow[t]{12}{*}{ Home language } & Afrikaans & 51 & 19.60 \\
\hline & English & 10 & 3.80 \\
\hline & Sepedi & 23 & 8.80 \\
\hline & Sesotho & 19 & 7.30 \\
\hline & Setswana & 10 & 3.80 \\
\hline & siSwati & 16 & 6.20 \\
\hline & Tshivenda & 7 & 2.70 \\
\hline & isiNdebele & 45 & 17.30 \\
\hline & isiXhosa & 9 & 3.50 \\
\hline & isizulu & 55 & 21.20 \\
\hline & isiTsonga & 14 & 5.40 \\
\hline & Other & 0 & 0.00 \\
\hline \multirow[t]{2}{*}{ Employment status } & Full-time & 225 & 98.00 \\
\hline & Part-time & 5 & 2.00 \\
\hline \multirow[t]{2}{*}{ Union membership } & Yes & 203 & 78.10 \\
\hline & No & 6 & 2.30 \\
\hline
\end{tabular}

Where percentages do not add up to a $100 \%$, it is because of missing values.

$N=260$.

(strongly disagree) to 5 (strongly agree). The quantitative role overload scale was based on how the employees experience their work load (Beehr, Walsh \& Taber, 1976). Work load is typically measured against their time, for example, not enough time compared to their amount of work. An example item of this construct is 'I am given enough time to do what is expected of me in my job', whereas the qualitative role overload scale contained items based on how the employees experience the difficulty of their job and whether it is too demanding (Sverke, Hellgren \& Öhrming, 1999). An example item of this construct is 'I feel unreasonable demands in my work'. The Role clarity scale (Rizzo et al., 1970) contained items regarding the clear understanding of the roles and responsibilities of the employee, for example, 'I know exactly what is expected of me on a daily basis', measured on a scale of 1 (strongly disagree) to 5 (strongly agree). Previous reliability for a composite scale has been deemed acceptable ( $\alpha=0.71$; Masia \& Pienaar, 2011).

\section{Job insecurity}

The job insecurity scale was developed by Hellgren et al. (1999). The questionnaire consisted of seven items (three qualitative and four quantitative), measured on a 5-point scale ranging from 1 (strongly disagree) to 5 (strongly agree). The quantitative items measured future uncertainty and worry of employees regarding their employment. An example item 
of this construct is 'I am worried about being able to keep my job', whereas the qualitative job insecurity scale focuses on worries relating to losing important aspects in one's job. An example item of this construct is 'I worry about getting less stimulating work tasks in the future'. Here a combined job insecurity factor was also used as in previous research that has utilised the same scale (e.g. Masia \& Pienaar, 2011). Previous reliability for this scale has been deemed acceptable $(\alpha \geq 0.70$; Masia \& Pienaar, 2011).

\section{Union support}

The union support scale is an adapted version of the scale of Shore et al. (1994) and consisted of five items. An example item of this construct is 'I can always call upon my union with questions or problems', measured on a 5-point scale ranging from 1 (strongly disagree) to 5 (strongly agree).

\section{Job satisfaction}

The job satisfaction scale is based on three items and was developed by Hellgren, Sjöberg and Sverke (1997). An example item of this construct is 'I am satisfied with my job', measured on a 5-point scale ranging from 1 (strongly disagree) to 5 (strongly agree). Previous reliability for this scale has been deemed acceptable ( $\alpha=0.75$; Masia \& Pienaar, 2011).

\section{Safety motivation and behaviour}

The safety motivation and behaviour scales were developed by Neal, Griffin and Hart (2000). The two scales were combined in this study because of an almost perfect correlation between the two estimated latent variables, indicating that participants did not fully discriminate between the items of the two separate constructs. Safety motivation was measured by four items and investigated the extent to which employees believe health and safety are important issues in the workplace. An example item of this construct is 'I believe that workplace health and safety is an important issue', measured on a 5-point scale ranging from 1 (strongly disagree) to 5 (strongly agree). Previous reliability for this scale has been deemed acceptable ( $\alpha=0.85$; Neal et al., 2000). Safety behaviour was measured by three items that measured safety behaviour and compliance. An example item of this construct is 'I carry out my work in a safe manner', measured on a 5-point scale ranging from 1 (strongly disagree) to 5 (strongly agree). Previous reliability for this scale has been deemed acceptable $(\alpha=0.72$; Vinodkumar \& Bhasi, 2010).

\section{Research procedure}

The research proposal was approved by the faculty research committee as part of the first author's master's degree at the North-West University. Permission was obtained to implement the project at the mining locations. At first, an email regarding the importance of the study was sent to the participants, explaining what the research was about, confidentiality regarding the assessment, assurance that participation would be free and fair and that withdrawal from the project would be without any negative consequences. The questionnaires were sent electronically to the shift bosses and supervisors who participated in the study, although participation was still voluntary.

\section{Statistical analysis}

To calculate the reliability of constructs (i.e. internal consistency), alpha coefficients are normally utilised (Cronbach, 1951). However, because of its inaccurate estimate of internal consistency and in some cases a gross overestimate of the correlation between test scores (Revelle \& Zinbarg, 2009), other alternatives such as the omega coefficients with 95\% confidence intervals have been proposed and it has been requested to abandon alpha (Peters, 2014). The authors of this study heeded that call and calculated omega coefficients.

Furthermore, structural equation modelling (SEM) methods were implemented with Mplus 7.2 (Muthén \& Muthén, 2014), that is, confirmatory factor analysis (CFA) was used to constitute a measurement model. All latent factors were constructed with their corresponding individual items as observed indicators. Thus, no item parcelling, mean score or sum score methods were used in this study. Only after the measurement model had been estimated and considered would regressions be added to the model to establish the structural model for the study. The estimation method used to investigate the model was the mean and variance-adjusted weighted least squares approach (WLSMV estimator), which is more suited to data that are categorical in nature, and this estimator is also robust against the potential of data nonnormality.

The following model fit statistics were considered to ascertain model fit: Comparative Fit Index (CFI), Tucker-Lewis Index (TLI) and the Root-Mean-Square Error of Approximation (RMSEA) (Van De Schoot, Lugtig \& Hox, 2012). For the CFI and TLI, values of 0.90 and above are generally considered acceptable (Van de Schoot et al., 2012) and for the RMSEA values below 0.08 are generally considered acceptable, but models should only be rejected if the RMSEA value is $\geq 0.10$ and when other fit indices are acceptable (Van De Schoot et al., 2012).

Statistical significance levels were set at the $95 \%$ confidence level $(p \leq 0.05)$, and the effect sizes for correlation coefficients were considered to be small $(r \leq 0.29)$, medium $(r \geq 0.30)$ or large effects $(r \geq 0.50)$ (Cohen, 1988). Even though mediation models are more suited to longitudinal studies in addressing the issue of time (Selig \& Preacher, 2009), the hypothesised relationships were deemed to be of such a nature that potential indirect effects could be evident, even in crosssectional data. Thus, to be completely thorough in this study, it was decided to investigate these potential effects. This was done with the MODEL INDIRECT function in Mplus and using the bootstrapping method with a request for 5000 resampling draws and confidence intervals at the $95 \%$ lower and upper level for the indirect effects (Muthén \& Muthén, 2014; Rucher, Preacher, Tormala \& Petty, 2011). 


\section{Results}

\section{Model fit}

Results from the CFA revealed that the measurement model fit the data. More specifically, the following values were generated for the considered fit indices: CFI (0.93), TLI (0.93), and RMSEA (0.06). The regression paths were then added to the model in order to specify the structural model (see Figure 1). The results of the structural model revealed that this model also fitted the data well: CFI (0.91), TLI (0.90) and RMSEA (0.07). Based on the acceptable fit criteria, it was deemed appropriate to continue interpreting the results of the correlation matrix, the structural regressions and any potential indirect effects that might be evident in the model.

\section{Correlations and omega reliability}

Table 2 presents the omega reliabilities with 95\% lower and upper confidence intervals and the correlation matrix for the latent variables.

The omega reliabilities of all the scales were acceptable $(\omega>0.70)$, implying that all the scales used in this study were reliable. The correlation matrix revealed that only union support was statistically significantly positively correlated with all the other variables, but only to a practical degree with job satisfaction ( $r=0.41$; medium effect). The largest correlation was between job satisfaction and safety motivation and behaviour ( $r=0.60$; large effect). It is evident that job insecurity was negatively related to both job satisfaction $(r=-0.30$; with a medium effect) and safety motivation and behaviour. Furthermore, data in Table 2 indicate that role stressors were negatively related to job satisfaction and safety

TABLE 2: Omega reliabilities and correlation matrix of the latent variables.

\begin{tabular}{|c|c|c|c|c|c|c|}
\hline \multirow{2}{*}{ Variable name } & \multirow[t]{2}{*}{$\omega$} & \multicolumn{5}{|c|}{$r$} \\
\hline & & 1 & 2 & 3 & 4 & 5 \\
\hline Job insecurity & $0.79[0.74,0.84]$ & 1.00 & - & - & - & - \\
\hline Work stressors & $0.83[0.80,0.85]$ & $0.56^{* *}$ & 1.00 & - & - & - \\
\hline Job satisfaction & $0.86[0.80,0.89]$ & $-0.30 *$ & $-0.36 *$ & 1.00 & - & - \\
\hline Union support & $0.76[0.69,0.82]$ & 0.18 & 0.17 & 0.41 & 1.00 & - \\
\hline $\begin{array}{l}\text { Safety motivation } \\
\text { and behaviour }\end{array}$ & $0.89[0.86,0.91]$ & -0.06 & -0.29 & $0.60 * *$ & $0.41^{*}$ & 1.00 \\
\hline
\end{tabular}

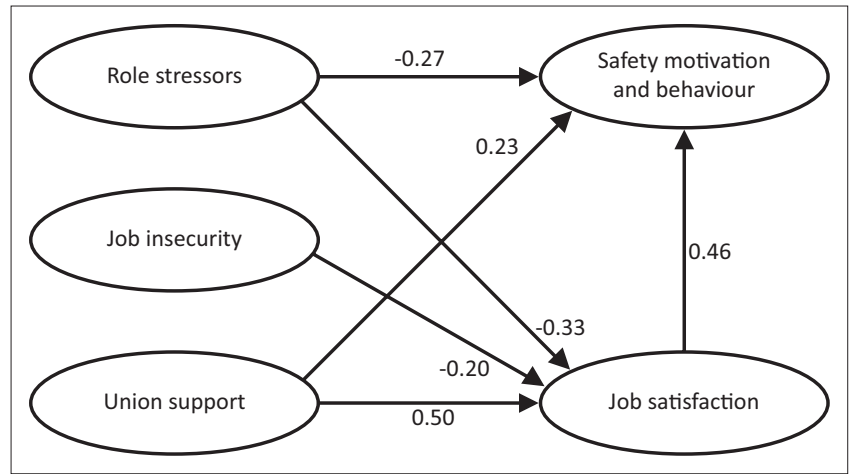

FIGURE 1: Structural model with the significant regression results. motivation behaviour. Additionally, a positive relationship (with medium effect; $r=0.41$ ) was found between union support and job satisfaction. Lastly, the results indicate that union support and safety motivation and behaviour are positively correlated (with medium effect; $r=0.41$ ).

\section{Structural paths}

Table 3 presents the structural relationships of the hypothesised model.

The regressions of the structural model indicate that role stressors had a significant negative predictive relationship with both job satisfaction $(\beta=-0.33 ; p=0.01)$ and safety motivation and behaviour $(\beta=-0.27 ; p=0.01)$. Furthermore, it was found that job insecurity had a negative relationship with job satisfaction $(\beta=-0.20 ; p=0.03)$, but no significant relationship with safety motivation and behaviour $(\beta=0.19$; $p=0.08)$. Union support had a positive relationship with both job satisfaction $(\beta=0.50 ; p=0.01)$ and safety motivation and behaviour ( $\beta=0.23$; $p=0.01$ ). Finally, it is evident that job satisfaction had a significant positive relationship with safety motivation and behaviour $(\beta=0.46 ; p=0.01)$.

\section{Indirect effects}

Concerning the indirect effects of the model, bootstrapping mediation analysis revealed that only one of the indirect effects was significant, that is, the mediating effect of job satisfaction between union support and safety motivation and behaviour: $0.26,95 \%$ confidence interval $(0.13 ; 0.39)$. Furthermore, as the direct effect from union support to safety motivation and behaviour was also statistically significant, this mediating effect can be classified as a complementary mediation as per the guidelines of Zhao, Lynch and Chen (2010) - as there was not only an indirect effect (which would indicate an indirect-only mediation) but also a direct path that was significant.

\section{Discussion}

The primary purpose of this study was to investigate the relationship between work stressors, job insecurity, union support, job satisfaction and safety motivation and behaviour

TABLE 3: Structural relationships of the hypothesised model.

\begin{tabular}{lllll}
\hline $\begin{array}{l}\text { Specified regression path } \\
\text { relationship }\end{array}$ & $\boldsymbol{\beta}$ & SE & $\boldsymbol{p}$ & Result \\
\hline $\begin{array}{l}\text { Work stressors } \rightarrow \text { Job } \\
\text { satisfaction }\end{array}$ & -0.33 & 0.09 & 0.01 & Significant \\
$\begin{array}{l}\text { Work stressors } \rightarrow \text { Safety } \\
\text { motivation and behaviour }\end{array}$ & -0.27 & 0.10 & 0.01 & Significant \\
$\begin{array}{l}\text { Job insecurity } \rightarrow \text { Job } \\
\text { satisfaction }\end{array}$ & -0.20 & 0.10 & 0.03 & Significant \\
$\begin{array}{l}\text { Job insecurity } \rightarrow \text { Safety } \\
\text { motivation and behaviour }\end{array}$ & 0.19 & 0.10 & 0.08 & $\begin{array}{l}\text { Not } \\
\text { significant }\end{array}$ \\
$\begin{array}{l}\text { Union support } \rightarrow \text { Job } \\
\text { satisfaction }\end{array}$ & 0.50 & 0.06 & 0.01 & Significant \\
$\begin{array}{l}\text { Union support } \rightarrow \text { Safety } \\
\text { motivation and behaviour }\end{array}$ & 0.23 & 0.09 & 0.01 & Significant \\
$\begin{array}{l}\text { Job satisfaction } \rightarrow \text { Safety } \\
\text { motivation and behaviour }\end{array}$ & 0.46 & 0.09 & 0.01 & Significant \\
\hline $\begin{array}{l}\beta, \text { Beta coefficient; SE, standard error. } \\
p=\text { statistical significance }\end{array}$ & & & &
\end{tabular}


in the iron ore mining industry. To accomplish the abovementioned aims, confirmatory factor analysis, SEM and indirect effects were implemented and estimated.

The first objective of the study was to determine the relationship between role stressors and job satisfaction. Results revealed that role stressors were negatively related to job satisfaction, confirming Hypothesis 1a. Recent research reported by Ling, Bahron and Boroh (2014) also found that work stressors had a negative relationship with job satisfaction. This further reinforced previous research in that the higher the role stress, the lower the job satisfaction (Karatepe, Yavas, Babakus \& Avci, 2006; Koustelios, Theodorakis \& Goulimaris, 2004; Morley \& Flynn, 2003; Zeffane \& McLoughlin, 2006).

The second objective was to determine the relationship between work stressors and safety motivation and behaviour. It was anticipated that these constructs would be negatively related. The results confirmed this relationship, providing evidence for Hypothesis $1 \mathrm{~b}$. This finding can be explained in the light of workers' tendency to engage in unsafe behaviour when confronted with stressful work situations. This may include taking short-cut methods, or otherwise compromising safety compliance that may cause injuries and accidents. These findings suggest that employees' compliance with safety rules and regulations reduces proportionately to their increased levels of stress at work (Ashworth \& Peake, 1994; Hofmann, Jacobs \& Landy, 1995).

The next objective of this study was to investigate the relationship between job insecurity and job satisfaction. It was hypothesised that job insecurity is negatively related to job satisfaction, and the result confirmed Hypothesis 2a. Previous empirical research also directly linked high levels of job insecurity to dissatisfaction with one's job (Näswall \& De Witte, 2003; Sverke \& Hellgren, 2002). In a more recent study conducted by Delp et al. (2010), also it was found that employees who experience job security are more likely to experience job satisfaction than those without this security.

Although it was predicted that employees' safety motivation and behaviour would be significantly impacted when their job security was threatened, a non-significant relationship was found between employees' perceived job insecurity and their safety motivation and behaviour. Hypothesis $2 b$ is therefore rejected. This finding can be explained in the light of a study done by Probst (1998), stating that a direct relationship between job insecurity and safety motivation is unlikely. It is rather expected that job insecurity leads to job dissatisfaction and, as a consequence, negative outcomes such as a lack of safety motivation and behaviour occur. A similar finding by Emberland and Rundmo (2010) also yielded no correlation between job insecurity and possible risk behaviour.

The next objective was to determine the relationship between union support and job satisfaction. As anticipated, a positive correlation and regression coefficient were found between union support and job satisfaction, substantiating Hypothesis $3 a$. Delp et al. (2010) provided evidence that employees who regarded union membership as important were more likely to experience job satisfaction than those who did not. Bender and Sloane (1998) emphasised that the aim of unions is to change working conditions that are poor, consequently engendering job satisfaction among employees. According to Porter and Steers (1973), the theory of need/value fulfilment suggests that the inconsistency between workers' needs and the degree to which their job meets their needs are negatively correlated to job satisfaction. Therefore, when unions address discrepancies, such as salaries and poor working conditions, employees may often feel their union is supporting them. When employees' needs are met, increased levels of job satisfaction can be expected (Probst \& Brubaker, 2001).

Furthermore, a positive relationship between union support and safety motivation and behaviour was confirmed (Hypothesis $3 b$ ). This finding can be explained by previous studies conducted on unionisation and workplace safety (cf. Dedobbeleer, Champagne \& German, 1990; Ringen et al., 1995; Suruda, Whitaker, Bloswick, Philips \& Sesek, 2002). Various ways in which unions aim to promote safety in workplace have been recorded. Therefore, unions play a crucial part in educating members about on-the-job hazards, providing them with incentives to be more cautious in the workplace, attracting more safety-conscious employees, encouraging workers to diminish known hazards, increasing supervisory inspections and developing safety-related innovations (Morantz, 2009).

As expected, strong evidence was found for the relationship between job satisfaction and workers' safety motivation and behaviour, which confirmed Hypothesis 4. This is congruent with research suggesting that employee satisfaction is often associated with decreased safety incident rates (Rossouw \& Bews, 2002). Dunbar (1993) also found a negative relationship between job insecurity and job dissatisfaction and employees' use of protective gear. In line with these findings, Robbins (1998) found that one of the ways employees may express job dissatisfaction could be to let conditions deteriorate, which may include reduced effort and increased error rate. Such actions, in turn, may relate to increased safety incident rates.

The last objective, which was to investigate the mediating role of job satisfaction between job insecurity, role stressors, union support and safety motivation and behaviour, was investigated by their indirect effects. It was anticipated that job satisfaction will mediate the relationship between job insecurity, role stressors, union support and safety motivation and behaviour. Results revealed that there was only a significant indirect effect of job satisfaction between union support and safety motivation and behaviour. Thus, Hypothesis 5 was only partially confirmed. Because the aim of unions is, among others, to change poor working conditions, actively engaged union members may experience unions as a basis of emotional support and a way to exert 
their power over decisions, consequently resulting in job satisfaction (Bender \& Sloane, 1998). Previous empirical studies have suggested that employees who showed high levels of job satisfaction also tended to have positive perspectives on the safety climate. Contrastingly, dissatisfied employees tended to have negative perspectives (Gyekye, 2005).

\section{Managerial implications}

Results indicated that mining organisations need to consider the implications of work stressors, job insecurity and union support on job satisfaction. The implication that job insecurity and union support can hold potential complications for employees' safety motivation and behaviour should be noted.

Organisations need to take cognisance of the relationships between role stressors, union support, job satisfaction, safety motivation and behaviour. Specifically, from the management's side, it is important to consider strategies to address role stressors and job insecurity and to enhance antecedents of job satisfaction in order to offset negative implications for safety outcomes. This could be done by gauging employee well-being levels and associated demands on a yearly basis with a valid and reliable measurement implemented in cooperation with the necessary professionals. Additionally, job satisfaction is also important for employee performance and health (Judge et al., 2001; Sverke et al., 2002). Work stressors can be addressed by ensuring fair demands in a feedback-rich environment for all employees and ensuring the clarity of roles and responsibilities in teams (Lang, Thomas, Bliese \& Adler, 2007; Whitaker, Dahling \& Levy, 2007).

In terms of addressing union support - which showed a positive effect on job satisfaction - it is more complicated as union and management goals may often be opposed. Engaging in constructive negotiations could prove fruitful, especially in light of possible retrenchments, which could add to existing job insecurity. However, union representatives may take note of this finding and ensure that their support of employees is communicated in clear fashion. As such, communicated support may contribute to enhanced job satisfaction.

\section{Limitations and recommendations}

Certain limitations are worth mentioning. Firstly, the use of a cross-sectional research design has restricted the study from confirming causal relationships about the expected relationships between variables. Furthermore, the present research study was conducted among a sample consisting exclusively of workers in a specific type of mine in the mining industry, even though it was the aim of the study. Likewise, the majority of the sample comprised black males. As these results cannot be generalised to the general population, it is suggested that future studies consider more heterogeneous samples in different unionised industries.
A non-probability, convenience sampling method was utilised in this research study. Consequently, participants partaking in the study varied across two mining organisations in different geographical locations. Issues regarding the selfreport questionnaires that were utilised in this study include accessing subjective factors, which may be influenced by a variety of factors and can play an essential role in the obtained results. Moreover, the variables of a self-report questionnaire could lead to common method variance between predictor variables and outcome variables (Malhotra, Kim \& Patil, 2006), although the means of addressing this problem are restricted (Salkind, 2009).

The current study adopted a more general view of trade unionism, and did not consider the type of unions, that is less or more militant and/or associated political affiliations. These aspects are important to consider for future research, also considering the union member exchange relationship. Furthermore, the study posited the social exchange theory as its theoretical foundation, but this theory is not without limitations. Specifically, the reciprocity of the exchange relationship may not be equal, as employers, employees and unions all have different power in their complex relationships. Other factors that could potentially be investigated are the relationship of union support with trust in the organisation and managerial-level variables such as management style and supervisor support, in the context of organisational support. The complexity of the relationship, wherein management and union objectives may often be antagonistic, needs to be explored where union support is additionally considered as having a positive and negative slant.

\section{Conclusion}

This study showed that work stressors and job insecurity were negatively associated with job satisfaction. Conversely, perceived union support was positively associated with job satisfaction and safety motivation and behaviour. Furthermore, job satisfaction mediated the relationship between union support and safety motivation and behaviour. Mining organisations can, by placing the focus on reducing work stressors, and addressing job security and the role of union support, achieve higher levels of safety motivation and behaviour through job satisfaction.

\section{Acknowledgements Competing interests}

The authors declare that they have no financial or personal relationships which may have inappropriately influenced them in writing this article.

\section{Authors' contributions}

This publication was based on the master's dissertation of N.W.H.S. L.T.D.B. was the co-supervisor of the project, acted as corresponding author, and performed the statistical analyses. J.P. was the supervisor for the research project and provided valuable inputs to the article. 


\section{References}

Acker, G.M. (2004). The effect of organizational conditions (role conflict, role ambiguity, opportunities for professional development, and social support) on job satisfaction and intention to leave among social workers in mental health care. Community Mental Health Journal, 40(1), 65-73. http://dx.doi.org/10.1023/ B:COMH.0000015218.12111.26

Ashford, S., Lee, C., \& Bobko, P. (1989). Content, causes, and consequences of job insecurity: A theory-based measure and substantive test. Academy of Management Journal, 32, 803-829. http://dx.doi.org/10.2307/256569

Ashworth, S.G.E., \& Peake, A.V. (1994). Assessment of the dominant circumstances and factors giving rise to accidents in the gold and Platinum Mining Industries. Pretoria, South Africa: SIMRAC.

Bakker, A., Demerouti, E., \& Schaufeli, W. (2003). Dual processes at work in a cal centre: An application of the job demands-resources model. European Journal of Work and Organizational Psychology, 12(4), 393-417. http://dx.doi. org/10.1080/13594320344000165

Bakker, A.B., \& Demerouti, E. (2007). The job demands-resources model: State of the art. Journal of Managerial Psychology, 22, 309-328. http://dx.doi.org/10.1108/ 02683940710733115

Balducci, C., Cecchin, M., \& Fraccaroli, F. (2012). The impact of role stressors on workplace bullying in both victims and perpetrators, controlling for personal vulnerability factors: A longitudinal analysis. Work \& Stress, 26(3), 195-212. http://dx.doi.org/10.1080/02678373.2012.714543

Barling, J., Kelloway, E.K., \& Iverson, R.D. (2003). High-quality work, job satisfaction and occupational injuries. Journal of Applied Psychology, 88(2), 276-283. http:// dx.doi.org/10.1037/0021-9010.88.2.276

Beehr, T.A., Walsh, J.T., \& Taber, T.D. (1976). Relationship of stress to individually and organisationally valued states: Higher order needs as a moderator. Journal of Applied Psychology, 61, 41-47. http://dx.doi.org/10.1037/0021-9010.61.1.41

Begley, P. (2013). Automation drives workers out of mining jobs. Retrieved n.d., from http://www.brisbanetimes.com.au/queensland/automation-drives-workers-outof-mining-jobs-20130726-2qph4.html

Bender, K., \& Sloane, P. (1998). Job satisfaction, unions, and exit-voice revisited. Industrial and Labor Relations Review, 51, 222-240. http://dx.doi.org/10.1177/ 001979399805100204

Blair, E. (1999). Behavioral safety: Myths, magic \& reality. Professional Safety, 44(8), 25.

Blanchflower, D., \& Oswald, A. (1999). Well-being, insecurity and the decline of American job satisfaction. Working paper. University of Warwick, UK.

Bolton, D., Bagraim, J.J., Witten, L., Mohamed, Y., Zvobgo, V., \& Khan, M. (2007). Explaining union participation: The effect of union commitment and demographic factors. SA Journal of Industrial Psychology, 33(1), 74-79. http://dx.doi.org/10. 4102/sajip.v33i1.254

Borjas, G.J. (1979). Job satisfaction, wages and unions. Journal of Human Resources, 14, 21-40. http://dx.doi.org/10.2307/145536

Borman, W.C., \& Motowidlo, S.J. (1993). Expanding the criterion domain to include elements of contextual performance. In N. Schmitt, \& W.C. Borman (eds.) Personnel selection in organizations (pp. 71-98). San Francisco: Jossey-Bass.

Bosak, J., Coetsee, W.J., \& Cullinane, S.J. (2013). Safety climate dimensions as predictors for risk behavior. Accident Analysis \& Prevention, 55, 256-264.

Carlson, D.S., Kacmar, M.K., \& Williams, L.J. (2000). Construction and validation of a multidimensional measure of work-family conflict. Journal of Vocational Behavior, 56(2), 249-276. http://dx.doi.org/10.1006/jvbe.1999.1713

Cheng, G.H.L., \& Chan, D.K.S. (2008). Who suffers more from job insecurity? A metaanalytic review. Applied Psychology: An International Review, 57, 272-303. http:// dx.doi.org/10.1111/j.1464-0597.2007.00312.x

Chirumbolo, A., \& Areni, A. (2005). The influence of job insecurity on job performance and absenteeism: The moderating effects of work attitudes. SA Journal of Industrial Psychology, 31(4), 65-71. http://dx.doi.org/10.4102/sajip.v31i4.213

Cohen, J. (1988). Statistical power analysis for the behavioral sciences. (2nd edn.). Hillsdale, NJ: Lawrence Erlbaum.

Cooper, C.L., Dewe, P.J., \& O'Driscoll, M.P. (2001). Organizational stress: A review of critique of theory, research, and applications. Thousand Oaks, CA: Sage.

Crawford, E.R., Lepine, J.A., Rich, B.L. (2010). Linking job demands and resources to employee engagement and burnout: A theoretical extension and meta-analytic test. Journal of Applied Psychology, 95(5), 834-848. http://dx.doi.org/10.1037/a0019364

Cregan, C. (2005). Can organizing work? An inductive analysis of individual attitudes toward union membership. Industrial and Labor Relations Review, 28(2), 282-304. http://dx.doi.org/10.1177/001979390505800207

Cronbach, L.J. (1951). Coefficient alpha and the internal structure of tests. Psychometrika, 22(3), 297-334. http://dx.doi.org/10.1007/BF02310555

Dedobbeleer, N., Champagne, F., \& German, P. (1990). Safety performance among union and non-union workers in the construction industry. Journal of Occupational Medicine, 32(11), 1099-1103. http://dx.doi.org/10.1097/00043764-199011000 00009

Delp, L., Wallace, S.P., Geiger-Brown, J., \& Muntaner, C. (2010). Job stress and job satisfaction: Home care workers in a consumer-directed model of care. Health Services Research, 45(4), 922-940. http://dx.doi.org/10.1111/j.1475-6773. 2010.01112.x

Demerouti, E., Bakker, A.B., Nachreiner, F., \& Schaufeli, W.B. (2001). The job demandsresources model of burnout. Journal of Applied Psychology, 86(3), 499-512. $\mathrm{http}: / / \mathrm{dx}$.doi.org/10.1037/0021-9010.86.3.499
Department of Mineral Resources. (2013). Annual report for 2012/2013. Retrieved November 15, 2015, from http://www.dmr.gov.za

De Witte, H. (1999). Job insecurity and psychological well-being: Review of the literature and exploration of some unresolved issues. European Journal of Work and Organizational Psychology, 8(2), 155-177. http://dx.doi.org/10.1080/ 135943299398302

De Witte, H., Pienaar, J., \& De Cuyper, N. (2016). Review of 30 years of longitudinal studies on the association between job insecurity and health and well-being: Is there causal evidence? Australian Psychologist, 51(1), 18-31. http://dx.doi. org/10.1111/ap.12176

Dunbar, E. (1993). The role of psychological stress and prior experience in the use of personal protective equipment. Journal of Safety Research, 24, 181-187. http:// dx.doi.org/10.1016/0022-4375(93)90029-M

Eisenberger, R., Huntington, R., Hutchison, S., \& Sowa, D. (1986). Perceived organizational support. Journal of Applied Psychology, 71, 500-507. http://dx.doi. org/10.1037/0021-9010.71.3.500

Emberland, J.S., \& Rundmo, T. (2010). Implications of job insecurity perceptions and job insecurity responses for psychological well-being, turnover intentions and risk behavior. Safety Science, 48, 452-459. http://dx.doi.org/10.1016/j.ssci.2009.12.002

Fried, Y., Shirom, A., Gilboa, S., \& Cooper, C. (2008). The mediating effects of job satisfaction and propensity to leave on role stress-job performance relationships: Combining meta-analysis and structural equation modeling. International Journa of Stress Management, 15, 305-328. http://dx.doi.org/10.1037/a0013932

Ghosh, A.K., Bhattacherjee, A. \& Chau, N. (2004). Relationships of working conditions and individual characteristics to occupational injuries: A case-control study of coal miners. Journal of Occupational Health, 46, 470-478. http://dx.doi.org/10.1539/ joh.46.470

Gilboa, S., Shirom, A., Fried, Y., \& Cooper, C. (2008). A meta-analysis of work demand stressors and job performance: Examining main and moderating effects. Personnel Psychology, 61(2), 227-271. http://dx.doi.org/10.1111/j.1744-6570.2008.00113.x

Gillen, M., Baltz, D., Gassel, M., Kirsch, L., \& Vaccaro, D. (2002). Perceived safety climate, job demands, and coworker support among union and non-union injured construction workers. Journal of Safety Research, 33(1), 33-51. http://dx.doi. org/10.1016/S0022-4375(02)00002-6

Goslinga, S., Hellgren, J., Chirumbolo, A., De Witte, H., Näswall, K., \& Sverke, M. (2005). The role of union support in coping with job insecurity: A study among union members from three European countries. SA Journal of Industria Psychology, 31(4), 72-78. http://dx.doi.org/10.4102/sajip.v31i4.215

Goslinga, S., \& Sverke, M. (2003). Atypical work and union membership: Union attitudes and union turnover among traditional vs. atypically employed union members. Economic and Industrial Democracy, 24(2), 290-312. http://dx.doi. org $/ 10.1177 / 0143831 \times 03024002007$

Greenhalgh, L., \& Rosenblatt, Z. (1984). Job insecurity: Toward conceptual clarity Academy of Management Review, 3, 438-448.

Griffeth, R.W., Hom, P.W., \& Gaertner, S. (2000). A meta-analysis of antecedents and correlates of employee turnover: Update, moderator tests, and research implications for the next millennium. Journal of Management, 26(3), 463-488. http://dx.doi.org/10.1177/014920630002600305

Griffin, M.A., \& Neal, A. (2000). Perceptions of safety at work: A framework for linking safety climate to safety performance, knowledge, and motivation. Journal of Occupational Health Psychology, 5, 347-358. http://dx.doi.org/10.1037/10768998.5.3.347

Gyekye, A.S. (2005). Workers' perceptions of workplace safety and job satisfaction International Journal of Occupational Safety and Ergonomics, 11, 291-302. http:// dx.doi.org/10.1080/10803548.2005.11076650

Hartley, J., Jacobson, D., Klandermans, B. \& Van Vuuren, T. (1991). Job insecurity. Coping with jobs at risk. London, UK: Sage Publications.

Hayes, B.E., Pernader, J., Smecko, T., \& Trask, J. (1998). Measuring perceptions of workplace safety: Development and validation of the work safety scale. Journal of Safety Research, 29(3), 145-161. http://dx.doi.org/10.1016/S0022-4375(98) Safety Rese
$00011-5$

Hellgren, J., \& Chirumbolo, A. (2003). Can union support reduce the negative effects of job insecurity on well-being? Economic and Industrial Democracy, 24, 271-289. http://dx.doi.org/10.1177/0143831X03024002006

Hellgren, J., Sjöberg, A., \& Sverke, M. (1997). Intention to quit: Effects of job satisfaction and job perceptions. In F. Avallone, J. Arnold, \& K. De Witte (Eds.), Feelings work in Europe (pp. 415-423). Milano, Italy: Guerini.

Hellgren, J., Sverke, M., \& Isaksson, K. (1999). A two-dimensional approach to job insecurity: Consequences for employee attitudes and well-being. European Journal of Work and Organization Psychology, 8, 179-195. http://dx.doi. org/10.1080/135943299398311

Hofmann, D.A., Jacobs, R., \& Landy, F. (1995). High reliability process industries: Individual, micro, and macro organisational influences on safety performance. Journal of Safety Research, 26, 131-149. http://dx.doi.org/10.1016/0022 4375(95)00011-E

Hofmann, D.A., \& Stetzer, A. (1998). The role of safety climate and communication in accident interpretation: Implication from negative events. Academy of Management Journal, 41, 644-657. http://dx.doi.org/10.2307/256962

Jackson, S., \& Schuler, R. (1985). A meta-analysis and conceptual critique of research on role ambiguity and role conflict in work settings. Organizational Behavior and Human Decision Processes, 36, 16-78. http://dx.doi.org/10.1016/0749-5978(85) 90020-2

Janssens, M.J., Brett, J.M., \& Smith, F.J. (1995). Confirmatory cross-cultural research Testing the viability of a corporation-wide safety policy. Academy of Management Journal, 38, 364-382. http://dx.doi.org/10.2307/256684 
Judge, T.A., Thoresen, C.J., Bono, J.E., \& Patton, G.K. (2001). The job satisfaction-job performance relationship: A qualitative and quantitative review. Psychological Bulletin, 127(3), 376-407. http://dx.doi.org/10.1037/0033-2909.127.3.376

Kahn, R.L., Wolfe, D.M., Quinn, R.P., Snoek, J.D., \& Rosenthal, R.A. (1964). Organizational stress: Studies in role conflict and ambiguity. New York: Wiley.

Kaiser, L. (2002). Job satisfaction: A comparison of standard, non-standard, and selfemployment patterns across Europe with a special note to the gender/jo satisfaction paradox. EPAG Working Paper 27, Colchester: University of Essex.

Karasek, R.A., \& Theorell, T. (1990). Healthy work: Stress, productivity and the reconstruction of working life. New York: Basic Books.

Karatepe, O.M., Yavas, V., Babakus, E., \& Avci, T. (2006). Does gender moderate the effects of role stress in frontline service jobs? Journal of Business Research, 59, 1087-1093. http://dx.doi.org/10.1016/j.jbusres.2006.08.004

Karsh, B., Booske, B.C., \& Sainfort, F. (2005). Job and organizational determinants of nursing home employee commitment, job satisfaction and intent to turnover Ergonomics, 48(10), 1260-1281. http://dx.doi.org/10.1080/00140130500197195

Katz, D., \& Kahn, R.L. (1978). The social psychology of organizations. (2nd edn.). New York: Wiley

Kenny, B., \& Bezuidenhoud, A. (1999). Contracting, complexity and control: An overview of the changing nature of subcontracting in the South African mining industry. The Journal of the South African Institute of Mining and Metallurgy, 99(4), 185-192.

Kochan, T.A., Katz, H.C., \& McKersie, R. (1986). The transformation of U.S. industrial relations. New York: Basic Books, Inc.

Koustelios, A., Theodorakis, N., \& Goulimaris, D. (2004). Role ambiguity, role conflict and job satisfaction among physical education teachers in Greece. The and job satisfaction among physical education teachers in Greece. The
International Journal of Educational Management, 18(2), 87-92. http://dx.doi. International Journal of Educational
org/10.1108/09513540410522216

Kumo, W.L., Rielander, J., \& Omilola, B. (2014). South Africa: 2014. Retrieved Octobe 10, 2015, from http://www.africaneconomicoutlook.org/fileadmin/uploads/ 10,2015 , from http://www.africaneconomicoutlo:
aeo/2014/PDF/CN Long_EN/Afrique du Sud EN.pdf

Lang, J., Thomas, J.L., Bliese, P.D., \& Adler, A.B. (2007). Job demands and job performance: The mediating effect of psychological and physical strain and the moderating effect of role clarity. Journal of Occupational Health Psychology, 12(2) moderating effect of role clarity. Journal of Occupational Heal

Le Roux, A. (2005). Mine fatalities down, but still too high. Mining weekly. Retrieved May 15, 2016, from http://www.miningweekly.co.za/min/features/health/?show=66581

Lillydahl, J.H., \& Singell, L.D. (1993). Job satisfaction, salaries and unions: The determination of university faculty compensation. Economics of Education Review, 12(3), 233-243. http://dx.doi.org/10.1016/0272-7757(93)90006-3

Ling, A.W., Bahron, A., \& Boroh, R.P. (2014). A study on role stress and job satisfaction among bank employees in Kota Kinabalu, Sabah. International Journal of Research in Management \& Business Studies, 1(2), 19-23.

Locke, E.A. (1969). What is job satisfaction? Organisational Behaviour and Human Performance, 4, 309-336. http://dx.doi.org/10.1016/0030-5073(69)90013-0

Malhotra, N.K., Kim, S.S., \& Patil, A. (2006). Common method variance in IS research: A comparison of alternative approaches and a reanalysis of past research. Management comparison of alternative approaches and a reanalysis of past research. M

Marrian, N. (2015). Job losses are social threat, says Mantashe. Retrieved December 10, 2015 from http://www.bdlive.co.za/economy/2015/07/28/job-losses-are-asocial-threat-says-mantashe

Masia, U., \& Pienaar, J. (2011). Unravelling safety compliance in the mining industry Examining the role of work stress, job insecurity, satisfaction and commitment as antecedents. South African Journal of Industrial Psychology, 37(1), 1-10. http:// dx.doi.org/10.4102/sajip.v37i1.937

Mathieu, J.E., \& Zajac, D.M. (1990). A review and meta-analysis of the antecedents, correlates, and consequences of organizational commitment. Psychological Bulletin, 108(2), 171-194. http://dx.doi.org/10.1037/0033-2909.108.2.171

Morantz, A. (2009, January). The elusive union safety effect: Toward a new empirical research agenda. 61st Annual Meeting (p. 130). Labor and Employment Relation Association: Champaign, IL.

Morley, M.J., \& Flynn, M. (2003). The relationship between work-role characteristics and intercultural transitional adjustment domain patterns among a sample of US and Canadian expatriates on assignment in Ireland. Cross Cult
10(3), 42-57. http://dx.doi.org/10.1108/13527600310797630

Muthén, L.K., \& Muthén, B.O. (2014). Mplus user's guide. (6th edn.). Los Angeles, CA: Muthén and Muthén.

Näswall, K., \& De Witte, H. (2003). Who feels insecure in Europe? Predicting job insecurity from background variables. Economic and Industrial Democracy, 24(2) 189-215. http://dx.doi.org/10.1177/0143831X03024002003

Neal, A., \& Griffin, M.A. (2006). A study of the lagged relationships among safety climate, safety motivation, safety behavior, and accidents at the individual and group levels. Journal of Applied Psychology, 91(4), 946-953. http://dx.doi. org/10.1037/0021-9010.91.4.946

Neal, A., Griffin, M.A., \& Hart, P.M. (2000). The impact of organizational climate on safety climate and individual behavior. Safety Science, 34, 99-109. http://dx.doi. org/10.1016/S0925-7535(00)00008-4

O'Driscoll, M.P., \& Beehr, T.A. (1994). Supervisor behaviors, role stressors and uncertainty as predictors of personal outcomes for subordinate. Journal of Organizational Behavior, 15, 141-155. http://dx.doi.org/10.1002/job.4030150204

Orgambídez-Ramos, A., Borrego-Alés, Y., \& Mendoza-Sierra, I. (2014). Role stress and work engagement as antecedents of job satisfaction in Spanish workers. Journal of Industrial Engineering and Management, 10(1), 360-372. http://dx.doi. org/10.3926/jiem.992
Örtqvist, D., \& Wincent, J. (2006) Prominent consequences of role stress: A metaanalytic review. International Journal of Stress Management, 13, 399-422. http:// dx.doi.org/10.1037/1072-5245.13.4.399

Ouyang, Z., Sang, J., Li, P., \& Peng, J. (2015). Organizational justice and job insecurity as mediators of the effect of emotional intelligence on job satisfaction: A study from China. Personality and Individual Differences, 76, 147-152. http://dx.doi. org/10.1016/j.paid.2014.12.004

Paul, P. S., \& Maiti, J. (2005). Development and test of a sociotechnical model for accident/injury occurrences in underground coal mines. Journal of South African Institute of Mining and Metallurgy, 105(1), 43-55.

Peters, G.J.Y. (2014). The alpha and the omega of scale reliability and validity. The European Health Psychologist, 16(2), 54-69.

Pienaar, J., Sieberhagen, C.F., \& Mostert, K. (2007). Investigating turnover intentions by role overload, job satisfaction and social support moderation. SA Journal of Industrial Psychology, 33(2), 62-67. http://dx.doi.org/10.4102/sajip.v33i2.378

Podsakoff, N.P., LePine, J.A., \& LePine, M.A. (2007). Differential challenge stressorhindrance stressor relationships with job attitudes, turnover intentions, turnover, and withdrawal behavior: A meta-analysis. Journal of Applied Psychology, 92(2), 438-454. http://dx.doi.org/10.1037/0021-9010.92.2.438

Porter, L.W., \& Steers, R.W. (1973). Organizational work, and personal factors in employee turnover and absenteeism. Psychological Bulletin, 80, 151-176. http:// dx.doi.org/10.1037/h0034829

Probst, T.M. (1998). Antecedents and consequences of job insecurity: Development and test of an integrated model, Doctoral dissertation, University of Illinois at Urbana Champaign.

Probst, T.M. (2002). Layoffs and offs: Production, quality, and safety demands under the threat of a job loss. Journal of Occupational Health Psychology, 7, 211-220. http://dx.doi.org/10.1037/1076-8998.7.3.211

Probst, T.M., \& Brubaker, T.L. (2001). The effects of job insecurity on employee safety outcomes: Cross-sectional and longitudinal explorations. Journal of Occupational Health Psychology, 6(2), 139-159. http://dx.doi.org/10.1037/1076-8998.6.2.139

Revelle, W., \& Zinbarg, R.E. (2009). Coefficients alpha, beta, omega, and the glb: Comments on Sijtsma. Psychometrika, 74, 145-154. http://dx.doi.org/10.1007/ s11336-008-9102-z

Rhoades, L., \& Eisenberger, R. (2002). Perceived organisational support: A review of the literature. Journal of Applied Psychology, 87(4), 698-714. http://dx.doi. org/10.1037/0021-9010.87.4.698

Rich, B.L., LePine, J.A., \& Crawford, E.R. (2010). Job engagement: Antecedents and effects on job performance. Academy of Management Journal, 53(3), 617-635. http://dx.doi.org/10.5465/AMJ.2010.51468988

Richter, A. (2011). Job insecurity and its consequences: Investigating moderators, mediators and gender. Stockholm University, Sweden.

Ringen, K., Englund, A., Welch, L., Weeks, J.L., \& Seegal, J.L. (1995). Why construction is different. Occupational Medicine, 10, 255-259.

Rizzo, J.R., House, R.J., \& Lirtzman, S.I. (1970). Role conflict and ambiguity in complex organizations. Administrative Science Quarterly, 15, 150-163. http://dx.doi. org $/ 10.2307 / 2391486$

Robbins, S.P. (1998). Organizational behavior. (5th edn.). Upper Saddle River, NJ: Prentice-Hall Inc.

Rossouw, D., \& Bews, N. (2002). The importance of trust in a changing business environment. Management Today, 18(2), 26-27.

Rucher, D.D., Preacher, K.J., Tormala, Z.L., \& Petty, R.E. (2011). Mediation analysis in social psychology: Current practices and new recommendations. Social and Personality Psychology Compass, 5(6), 359-371. http://dx.doi.org/10.1111/j. 1751-9004.2011.00355.x

Saks, A.M. (2006). Antecedents and consequences of employee engagement. Journa of Managerial Psychology, 21(7), 600-619. http://dx.doi.org/10.1108/ 02683940610690169

Salkind, N.J. (2009). Exploring research. (7th edn.). Upper Saddle River, NJ: Pearson.

Salminen, S. (1995). Does pressure from the work community increase risk taking? Psychology Report, 77, 1247-1250. http://dx.doi.org/10.2466/pr0.1995.77.3f.1247

Selig, J.P., \& Preacher, K.L. (2009). Mediation models for longitudinal data in developmental research. Research in Human Development, 6, 144-164. http:// dx.doi.org/10.1080/15427600902911247

Seseane, T., Jr. (2014). South African unions vie for control of militant workers. Retrieved March 19, 2015, from https://www.wsws.org/en/articles/2014/02/20/ safr-f20.html

Shore, L.M., Tetrick, L.E., Sinclair, R.R., \& Newton, L.A. (1994). Validation of a measure of perceived union support. Journal of Applied Psychology, 79, 971-977. http:// dx.doi.org/10.1037/0021-9010.79.6.971

Slichter, S.H., Healy, J.J., \& Livernash, E.R. (1960). The impact of collective bargaining on management. Washington, DC: Brookings Institution.

Smit, C. (2013, December). The role of mining in the South African economy. KPMG. Retrieved March 20, 2015, from http://www.sablog.kpmg.co.za/2013/12/rolemining-south-african-economy/

Smith, N.W.H. (2014). Assessing work stressors, union support, job satisfaction and safety outcomes in the mining environment. Unpublished mini-dissertation, North-West University, Potchefstroom, South Africa.

Spector, P. (1997). Job satisfaction: Application, assessment, causes and consequences. Thousand Oaks, CA: Sage.

Spigener, J., \& Hodson, S. (1997). Are labour unions in danger of losing their leadership position in safety? Professional Safety, 42(12), 37-39. 
Steyn, L. (2014, 27 June). Tsunami mining strike changes landscape. Mail \& Guardian Retrieved September 09, 2014 from http://mg.co.za/article/2014-06-26tsunami-mining-strike-changes-landscape

Stordeur, S., D'hoore, W., \& Vandenberghe, C. (2001). Leadership, organizational stress, and emotional exhaustion among hospital nursing staff. Journal of Advanced Nursing, 35, 533-542. http://dx.doi.org/10.1046/j.1365-2648.2001. 01885.x

Struwig, F.W., \& Stead, G.B. (2001). Planning, designing and reporting research. Cape Town, ZA: Pearson Education.

Suruda, A., Whitaker, B., Bloswick, D., Philips, P., \& Sesek, R. (2002). Impact of the OSHA trench and excavation standard on fatal injury in the construction industry. Journal of Occupational and Environmental Medicine, 44(10), 902-905. http:// dx.doi.org/10.1097/00043764-200210000-00007

Sverke, M., \& Hellgren, J. (2002). The nature of job insecurity: Understanding employment insecurity on the brink of a new millennium. Applied Psychology: An International Review, 51(1), 23-42. http://dx.doi.org/10.1111/1464-0597. $0077 z$

Sverke, M., Hellgren, J., \& Näswall, K. (2002). No security: A meta-analysis and review of job insecurity and its consequences. Journal of Occupational Health Psychology, 7, 242-264. http://dx.doi.org/10.1037/1076-8998.7.3.242

Sverke, M., Hellgren, J., Näswall, K., Chirumbolo, A., De Witte, H. \& Goslinga, S. (2004) Job insecurity and union membership: European unions in the wake of flexible production. Brussels: P.I.E.-Peter Lang.

Sverke, M., Hellgren, J., \& Öhrming, J. (1999). Organizational restructuring and health care work: A quasi-experimental study. In P.M. Le Blanc, M.C.W. Peeters, A. Bussing, \& W.B. Schaufeli (Eds.), Organisational psychology and health care European contributions (pp. 15-32). Munchen, Germany: Rainer Hampp Verlag.

Vandenberghe, C., Panaccio, A., Bentein, K., Mignonac, K., \& Roussel, P. (2011) Assessing longitudinal change of and dynamic relationships among role stressors, job attitudes, turnover intention, and well-being in neophyte newcomers. Journal of Organizational Behavior, 32(4), 652-671. http://dx.doi.org/10.1002/ job.732
Van De Schoot, R., Lugtig, P., \& Hox, J. (2012). A checklist for testing measurement invariance. European Journal of Developmental Psychology, 9, 486-492. http:// dx.doi.org/10.1080/17405629.2012.686740

Verma, A. (2005). What do unions do to the workplace? Union effects on management and HRM policies. Journal of Labor Research, 26, 417-451. http://dx.doi. org/10.1007/s12122-005-1013-5

Vinodkumar, M.N., \& Bhasi, M. (2010). Safety management practices and safety behaviour: Assessing the mediating role of safety knowledge and motivation. Accident Analysis \& Prevention, 42(6), 2082-2093. http://dx.doi.org/10.1016/j. aap.2010.06.021

Weil, D. (1992). Building safety: The role of construction unions in the enforcement of OSHA. Journal of Labor Research, 13(1), 121-132. http://dx.doi.org/10.1007/ BF02685455

Weil, D. (1999). Are mandated health and safety committees substitutes for or supplements to labor unions? Industrial \& Labor Relations Review, 52(3), 339360. http://dx.doi.org/10.1177/001979399905200301

Weiss, H.M., Nicholas, J.P., \& Daus, C.S. (1999). An examination of the joint effects of affective experiences and job beliefs on job satisfaction and variations in affective experiences over time. Organizational Behavior and Human Decision Processes, 78, 1-24. http://dx.doi.org/10.1006/obhd.1999.2824

Whitaker, B.G., Dahling, J.J., \& Levy, P. (2007). The development of a feedback environment and role clarity model of job performance. Journal of Management, 33(4), 570-591. http://dx.doi.org/10.1177/0149206306297581

Yousef, D.A. (2002). Job satisfaction as a mediator of the relationship between role stressors and organizational commitment: A study from an Arabic cultural perspective. Journal of Managerial Psychology, 17(4), 250-266. http://dx.doi. org/10.1108/02683940210428074

Zeffane, R., \& McLoughlin, D. (2006). Cooperation and stress: Exploring the differential impact of job satisfaction, communication and culture. Management Research News, 29(10), 618-631. http://dx.doi.org/10.1108/01409170610712326

Zhao, X., Lynch, J.G., \& Chen, Q. (2010). Reconsidering Baron and Kenny: Myths and truths about mediation analysis. Journal of Consumer Research, 37, 197-206. http://dx.doi.org/10.1086/651257 